\title{
Wyrok Sądu Metropolitalnego w Katowicach (c. Sobański) z 10.04.2000 r. z tytułu braku formy kanonicznej
}

Ius Matrimoniale 6 (12), 203-205

2001

Artykuł został zdigitalizowany i opracowany do udostępnienia w internecie przez Muzeum Historii Polski w ramach prac podejmowanych na rzecz zapewnienia otwartego, powszechnego i trwałego dostępu do polskiego dorobku naukowego i kulturalnego. Artykuł jest umieszczony w kolekcji cyfrowej bazhum.muzhp.pl, gromadzącej zawartość polskich czasopism humanistycznych i społecznych.

Tekst jest udostępniony do wykorzystania w ramach dozwolonego użytku. 
Ius Matrimoniale

6 (12) 2001

\section{Wyrok Sądu Metropolitalnego w Katowicach (c. Sobański) z 10.04.2000 z tytułu braku formy kanonicznej}

\section{Przebieg sprawy:}

PM oraz DO zawarli małżeństwo 28.01.1995 w kościele garnizonowym św. K. w K. Ważność tego małżeństwa została zaskarżona przez DO 16.09.1998 w Sądzie Metropolitalnym w Katowicach. Sprawę przyjęto do procesu 30.10.1998, a jego przedmiot ustalono 18.01.1999 w formie pytania: „Czy zachodzi nieważność małżeństwa stron z tytułu wykluczenia potomstwa przez pozwanego oraz/lub podstępnego wprowadzenia w błąd powódki przez pozwanego?". W trakcie procesu nasunęly się wątpliwości, czy małżeństwo zostało zawarte zgodnie $z$ przepisami prawa co do kanonicznej formy zawarcia małzeństwa. Ponieważ wątpliwości te okazały się zasadne, Sąd - przestrzegając normy kan. $1514-3.01 .2000$ uzupelnil przedmiot sprawy o pytanie, czy udowodniono nieważność małżeństwa z tytulu braku formy kanonicznej. Tak więc Sąd ma odpowiedzieć na pytanie, czy udowodniono nieważność małżeństwa w ustalonych trzech (wzgl. któregoś z nich) tytulów nieważności.

\section{Motywy prawne:}

(...) Katolików obowiązuje kanoniczna forma zawarcia małżeństwa i to do jego ważności ( $z$ wyjątkiem, o którym w kan. 1127 i 2). Polega ona na tym, że ,tylko te malżerístwa sq ważne, które zostajq zawarte wobec asystujacego miejscowego ordynariusza albo proboszcza, albo wobec kaptana lub diakona delegowanego przez jednego z nich; a także wobec dwóch świadków" (kan. 1108 1 1). Ordynariusz miejsca i proboszcz (parafii terytorialnej) asystują ważnie przy małżeństwach zawieranych w granicach ich terytorium (kan. 1109), natomiast ordynariusz i proboszcz personalny na mocy urzędu ważnie asystują jedynie przy małżeństwach nupturientów, z których przynajmniej jedno ,podlega im 
w granicach ich okregu" (kan. 1110). Ordynariusz miejsca i proboszcz parafii teryrtorialnej mogą delegować innych kapłanów i diakonów do asystowania przy małżeństwach zawieranych w granicach ich terytorium (kan. $1111_{1}$ 1), nie może natomiast udzielić takiej delegacji ordynariusz czy proboszcz personalny. Normy kan. 137 o delegowaniu wladzy rządzenia nie można bowiem stosować do uprawnień do asystowania przy zawarciu małżeństwa (w kan. 14412 wyraźnie stwierdza się, że w kan. 1111 jest mowa o uprawnieniach, a nie o władzy rządzenia). Jeśli więc małżeństwo zostaje zawarte w kościele parafii personalnej (np. garnizonowym), a żadne $z$ nupturientów nie należy do parafii personalnej, potrzebna jest - również dla proboszcza parafii personalnej - delegacja od miejscowego ordynariusza lub od proboszcza parafii, na której terytorium znajduje się kościół parafii personalnej. Również takiej, tj. od ordynariusza miejsca lub proboszcza parafii terytorialnej, delegacji potrzeba, jeśli któryś $z$ nupturientów podlega wprawdzie proboszczowi personalnemu, ale nie on ma asystować przy malżeństwie. Jeśli takiej delegacji brak, małżeństwo zostaje zawarte nieważnie $\mathrm{z}$ powodu braku formy kanonicznej. Przepisy kan. 144 znajdują zastosowanie jedynie do kan. $1111 \S 1$, nie zaś do kan. 1110.

Sąd musi przy okazji zwrócić uwagę na blędy w polskim przekładzie KPK. W kan. 1110 nie chodzi o ordynariusza miejsca, jak w polskim tekście, lecz o ordynariusza personalnego. $\mathrm{Z}$ kolei w oryginale łacińskim kan. $1111 \S 1$ wyraźnie powiedziano „loci ordinarius”, a więc ordynariusz miejsca, którego to dopełnienia brak w przekładzie polskim.

\section{Stan sprawy:}

(...) Malżeństwo stron zostało zawarte 28.01.1995 w kościele garnizonowym w K. Protokół przedślubny spisano w parafii M.B., na której terenie pozwany - jak wynika z protokołu - miał wówczas zamieszkanie. Zapowiedzi głoszono też w parafii św. P., na której terenie mieszkała powódka. Na protokole jest wzmianka ,licentia”, bez doprecyzowania, kto komu jej udziela (k. 45). Wedle pisma ówczesnego proboszcza garnizonu z 14.05.1999 (k. 40), potwierdzonego pismem obecnego proboszcza z 1.12.1999 (k. 50), małżeństwo było zawierane na podstawie licencji z parafii św. P. z 23.01.1999. Z kolei w piśmie z 12.12.1999 ks. TB ówczesny proboszcz garnizonu w K., donosi, że zgodę na pobłogosławienie tego związku wyraził na prośbę zastępcy dowódcy JW 
w K., w tym samym piśmie twierdzi, iż „por PM. służył w Garnizonie K. i jako żołnierz zawodowy należał do tej parafii" (k. 53). Ponadto ponownie wspomina licencję z parafii św. P. Wyjaśnienia te są niespójne. Gdyby p. PM. byl wówczas żolnierzem, proboszcz parafii wojskowej nie potrzebowalby na pobłogosławienie małżeństwa ani prośby dowódcy ani licencji z parafii. Z niepodejrzanych zeznań stron wynika, że pozwany odbywal służbę wojskową dopiero po zawarciu małżeństwa. Proboszcz garnizonu nie był więc w żaden sposób właściwy do pobłogosławienia tego związku. Ponieważ kościół garnizonowy, tzn. parafii (personalnej) wojskowej św. K., znajduje się na terytorium parafii św. P., małżeństwa osób nie podpadających pod właściwość proboszcza garnizonu mogą w tym kościele być zawierane - za zgodą proboszcza garnizonu - bez licencji z parafii św. P. (która to licencja nie jest zresztą wymagana do ważności), w obecności katowickiego ordynariusza miejsca lub proboszcza parafii św. P. wzgl. kapłana (lub diakona) delegowanego czy to przez ordynariusza czy to przez proboszcza parafii św. P. Tymczasem asystujący przy zawarciu małżeństwa stron nie mial delegacji ani od ordynariusza ani od proboszcza parafii św. P, lecz od proboszcza garnizonu (k. 40,50,53). Delegacja ta była w świetle wyłożonego wyżej stanu prawnego nieważna.

Biorąc powyższe pod uwagę Sąd stwierdza, iż nie udowodniono nieważności małżeństwa $z$ tytułów pierwotnie ustalonych, $\mathrm{tj}$. ani $\mathrm{z}$ tytułu podstępnego wprowadzenia powódki w błąd przez pozwanego ani z tytulu wykluczenia przezeń potomstwa. Udowodniono natomiast nieważność małżeństwa $\mathrm{z}$ tytulu braku formy kanonicznej. Tym samym Sąd orzeka, iż udowodniono nieważność małżeństwa.

\section{La sentenza del Tribunali di Katowice c. Sobański del 10. 4.2000 dal titolo „defectus formae”}

\section{Sommario}

Si presenta la sentenza del Tribunali Metropolitano di Katowice c. Sobaskiemu („pro nullitate”) do desectum formae. 